\title{
TIMO PANKAKOSKI
}

\section{P OLITIIKKA TAISTELUNA}

\section{MaX Weberin KOLMINKertainen $K A M P F$}

Ajatus politiikasta taisteluna, konfliktina ja sodankäyntinä on eräs sitkeimmistä taustaoletuksista poliittisen ajattelun historiassa. Sen hyvin erilaisia ja kenties yhteismitattomiakin ilmentymiä voidaan löytää esimerkiksi Niccolò Machiavellin, Carl von Clausewitzin, Friedrich Nietzschen, V. I. Leninin, Vilfredo Pareton, Georges Sorelin, Oswald Spenglerin, Carl Schmittin, Ernst Jüngerin ja lukuisten marxilaisten ajattelusta sekä - osin edellisten kerrannaisvaikutuksena - myöhemmin esimerkiksi Michel Foucault'lta ja Chantal Mouffelta. Kun moderneissa yhteiskuntatieteissä korostetaan sitä, että politiikka on perusluonteeltaan taistelua, on vähintään rivien välissä kuitenkin läsnä myös Max Weber (18641920). ${ }^{1}$ Usein Weberin auktoriteetti, karisma ja klassikkoaseman synnyttämä legitimoiva voima otetaan käyttöön myös suoraan.

Weber puhuukin politiikasta toistuvasti taisteluna (Kampf). Weberin poliittinen taistelu ei kuitenkaan tarkoita aina samaa, vaan sillä on useampia, toisiinsa kytkeytyviä käyttötapoja. Tässä artikkelissa tarkastelen näitä poliittisen taistelun eri merkityksiä. Luen Weberin politiikkakäsityksen kannalta keskeisiä tekstejä käsiteanalyyttisesti ja täydennän tätä näkökulmaa kontekstualisoivalla aatehistoriallisella luennalla. Esitän, että Weber puhuu politiikasta taisteluna kolmessa erillisessä merkityksessä, ja nimitän näitä taistelun käsitteen käyttötapoja "arvotaisteluksi", "aktiiviseksi taisteluksi" sekä "latentiksi valintataisteluksi".

Politiikka on arvotaistelua siksi, että maailma on lähtökohtaisesti konfliktuaalinen ja arvot, intressit ja vakaumukset ikuisesti ristiriitaisia ja yhteismitattomia. Tältä pohjalta myös politiikka on väistämättä hyvin perustavanlaatuisella ja koko inhimillisen olemassaolon juuriin ulottuvalla tavalla taisteluntäyteistä. Usein sanotaan, että "asiat taistelevat, eivät ihmiset", ja politiikka arvotaisteluna viittaa nimenomaan asioiden maailmassa ilmenevään konfliktuaalisuuteen. Politiikassa kuitenkin myös ihmiset taistelevat, ja aktivinen taistelu viittaa poliittisten toimijoiden tietoiseen pyrkimiseen, intressien edistämiseen ja päämäärien tavoittelemiseen. Tällainen taistelu tapahtuu usein rationaalisesti valituin keinoin ja on niukkuuden vallitessa ristiriidassa muiden toimijoiden avointen ja tunnustettujen valtapyrkimysten kanssa. Politiikka voi kuitenkin olla taistelua myös latentin valintataistelun merki- 
tyksessä: vaikka poliittiset toimijat eivät aktiivisesti ja tietoisesti taistelisikaan niukoista resursseista, voi poliittinen prosessi kokonaisuutena ja makrotasolla kuitenkin näyttäytyä sellaisena taistelu- ja valintaprosessina, joka tuottaa aatteiden, ideoiden ja ennen kaikkea kyvykkäimpien johtajien valikoitumisen.

Weberin eksplisiittiset toteamukset politiikasta taisteluna ja laveampi metaforinen puhe "poliittisesta taistelusta" saavat varsin erilaisia painotuksia, kun niitä tulkitaan näistä eri näkökulmista. ${ }^{2}$ Nähdäkseni weberiläisen politiikan taistelu-ulottuvuuden tasapainoinen tarkasteleminen edellyttää kaikkien kolmen taistelun muodon huomioimista. Osoitan tässä artikkelissa, että Weberille politiikka on taistelua, taistelua ja taistelua - yhden monoliittisen taistelun sijaan kolmea eri taistelua.

\section{TAISTELU MAAILMANKATSOMUKSENA}

Poliittinen taistelu on vain yksi laajemman taistelun kategorian alamuoto, ja siksi poliittisen taistelun ymmärtäminen edellyttää lyhyttä analyysia taistelusta ylipäänsä. Weberille taistelu on - Mommsenin (2004[1959], 50) sanoin - "inhimillisen olemassaolon peruskategoria", siis kaikkea kulttuuria määrittävä yleinen periaate. Taistelun idea istuu syvässä jo Weberin yleisessä maailmankuvassa, jota voidaan hyvällä syyllä luonnehtia "agonaaliseksi" eli kamppailuorientoituneeksi (esim. Winckelmann 1966, 240). Tämä on ymmärrettävä nimenomaan antiikista periytyvän, kulttuuria luovan ja ylläpitävän agonismin merkityksessä: Weberin taistelukäsityksellä on kreikkalaiset juurensa, mikä pohjautuu osin Weberin omaan antiikin kulttuurin tuntemukseen ja osin Jacob Burckhardtin ja tämän oppilaan Nietzschen tulkintoihin. ${ }^{3}$ Myös nietzscheläinen filosofia itsessään - antiikkitulkinnoista irrallaan - on epäilemättä vaikuttanut taistelun idean saamaan positiiviseen lataukseen.

Oma relevanssinsa on myös välittömällä aikalaiskontekstilla. Weberin ajan saksa- laista kulttuuria voidaan luonnehtia konfliktiorientoituneeksi, ja yleisesti ottaen taistelun käsitteeseen liittyi paljon myönteisiä konnotaatioita: taistelu kuvattiin usein arvokkaana, kasvattavana ja jalostavana toimintana sekä ihmisen osaan lähtökohtaisesti kuuluvana ilmiönä. ${ }^{4}$ Aatteiden ja kulttuurin tasolla esimerkiksi erilaisten voimapoliittisten, imperialististen ja rotuteoreettisten oppien syntyä ja populaaria vetoavuutta voidaan pitää osittain näiden myönteisten sävyjen heijastumana. Samansuuntaisia ajattelutapoja ja sanallisia muotoiluja tarjosivat myös esimerkiksi darwinilainen oppi olemassaolon taistelusta, radikaalimarxilainen luokkataisteluoppi, taistelun ja sodankäynnin vitaalisiksi voimiksi kuvannut nietzscheläinen elämänfilosofia sekä perinteinen kirkollinen retoriikka taistelusta pimeyden voimia vastaan. Taisteluja konfliktimyönteiset arvostukset näkyivät keisariajan Saksassa myös sosiaalisen elämän alueella, esimerkiksi valtiollisen elämän yleisessä militaristisuudessa ja kaksintaisteluinstituution vahvassa arvostuksessa. Myös Max Weber eli keisarillisen Saksan kulttuurissa sen akateemisen ja porvarillisen luokan jäsenenä ja epäilemättä jakoi joitain taistelun ilmiötä koskevista ajattelutavoista ja arvostuksista. Miehisyys, voima ja konflikti kummittelevat - osin ambivalentteina - rivien välissä tuon tuostakin, ja nämä teemat olivat paikoin vahvasti läsnä myös Weberin yksityiselämässä. ${ }^{5}$

Weberin käsitys taistelusta perustuu tiettyihin toisiaan lähellä oleviin ja toisiaan täydentäviin oletuksiin, jotka eivät kenties ole suoranaista seurausta nietzscheläisdarwinilaisista ajatusmalleista tai konfliktimyönteisistä aikalaisarvostuksista, mutta kuitenkin vähintäänkin sopusoinnussa niiden kanssa. Weberin agonistisen arvomaailman mukaisesti taistelu on ensinnäkin ikuista ja väistämätöntä: "Taistelua [Kampf] ei [...] voida karsia pois, vaan se on läsnä kaikessa kulttuurielämässä" (Wertfreiheit, 503). Toiseksi, vaikka taistelua ei voidakaan koskaan kokonaan sulkea ulos, sen muotoa voidaan kuitenkin muuttaa: "Sen 
[taistelun] keinoja, kohteita ja jopa sen perussuuntia ja sitä, ketkä taistelua käyvät, voidaan muuttaa" (Mts.).

Kolmanneksi taistelu ilmenee usealla eri tavalla ja voi olla luonteeltaan esimerkiksi taloudellista, poliittista, juridista, kulttuurista, uskonnollista tai tieteellistä ja se voi tapahtua yksittäisten ihmisten mikrotasolla, mutta yhtä hyvin esimerkiksi kansojen, rotujen, yhteiskuntaryhmien tai aatteiden välillä. Kyse on hyvin yleisestä, laaja-alaisesta ja hajanaisestakin periaatteesta, jonka kaikki muodot ovat saman yleisen ilmiön erilaisia muunnelmia. Tähän kytkeytyy neljäs olettamus, jonka mukaan nämä taistelun eri ilmentymät lisäksi muodostavat eheän jatkumon, joka ulottuu kirjaimellisesti väkivaltaisesta sodankäynnistä ja tappelusta aina rauhanomaisiin peleihin, kilpailuihin ja kamppailuihin: "Verisestä, vastustajan elämän tuhoamiseen pyrkivästä ja kaikki taistelusääntöjen sitovuudet hylkäävästä taistelusta [Kampf] on mitä saumattomin siirtymä muodollisesti säädeltyyn ritaritaisteluun [...] ja säädeltyyn kamppailu-urheiluun. Samoin voidaan siirtyä myös vaikkapa kosijoiden naisen suosiosta käymästä säännöttömästä 'kilpailusta' [Konkurrenz] tai markkinoiden sääntöjen sitomasta, vaihtomahdollisuuksista käytävästä kilpailusta [Konkurrenzkampf] aina säädeltyihin taiteellisiin 'kilpailuihin' tai 'vaalikamppailuun' ['Wahlkampf']." ( WuG, 20. Kursivoinnit lisätty.)

Viidenneksi eri taistelumuotojen välisten erojen varsinainen ydin on Weberin käsityksen mukaan nimenomaan taistelussa käytettävien keinojen luonteessa. Esimerkiksi "[v]äkivaltaisen taistelun käsitteellinen erottaminen perustuu sille normaalien keinojen omaleimaisuuteen ja niihin erityisluonteisiin sosiologisiin seurauksiin, jotka seuraavat väkivaltaisen taistelun esiin astumisesta” ( $W u G, 20)$. Rauhanomaisessa taistelussa sen sijaan käytetään rauhanomaisia välineitä: "Rauhanomaisiksi' taisteluvälineiksi kutsumme sellaisia, jotka eivät koostu tosiasiallisesta [aktueller] fyysisestä väkivaltaisuudesta" (Mts.).
Osa näistä oletuksista kietoutuu tiiviisti toisiinsa: nimenomaan siksi, ettei taistelua voida koskaan kokonaan sulkea ulos vaan se on ikuista, on pyrittävä muuttamaan sen muotoa, ja tämä taas tapahtuu parhaiten taisteluvälineitä säätelemällä. Näin syntyy suuri määrä sosiaalisessa maailmassa ilmeneviä taistelun, kamppailun ja kilpailun muotoja, jotka ovat joukko toisiaan muistuttavia ja katkoksitta toisiinsa kytkeytyviä saman periaatteen muunnoksia.

Nämä lähtökohdat tekevät taistelun kategoriasta niin kattavan, että myös monet täysin rauhanomaiset toiminnan muodot lukeutuvat sen piiriin. Rauhanomaista taistelua Weber nimittää kilpailuksi (Konkurrenz) (mts.), ja esimerkiksi Georg Simmelin (1995[1903]) tavoin hän näkee kilpailun nimenomaan laajemman taistelun kategorian alatapauksena. Kilpailu on pitkälle kehittyneelle järjestykselle tyypillistä, pelisääntöjen säätelemää toimintaa ( $K a$ tegorien, 464), joka näyttää eroavan muista taistelun muodoista - esimerkiksi sodankäynnistä ja kamppailu-urheilusta - lähinnä määrällisesti eli vähemmän väkivaltaisuuden asteen nojalla, ei laadullisesti. Weberin perusoletusten pohjalta paradoksaalisesti myös rauha muuttuu taisteluksi ja tarkoittaa vain "taistelumuotojen tai taisteluvastustajien tai taistelukohteiden ja valintamahdollisuuksien muuntumista" (Wertfreiheit, 503). Siten myös rauhanomainen politiikka voi kuitenkin olla taistelua.

\section{POLITIIKKA ARVOTAISTELUNA}

Saksalaisen kulttuurin konfliktipainotukset, Weberin agonistinen maailmankuva ja käsitellyt taistelua koskevat oletukset johdattavat suoraan Weberin ensimmäisen taistelun käsitteen poliittisen käyttötavan jäljille. Weberille elämä maan päällä on ikuisesti konfliktuaalista, eikä "liikkumatilaa maallisessa olemassaolossa" voida saavuttaa muuten kuin "ihmisen ankarassa taistelussa ihmisen kanssa [im harten Kampf des Menschen mit dem Menschen]" (Nationalstaat, 558). Tulkintani mukaan politiikka 
on Weberille taistelua siksi, että ihmiselämä ylipäänsä on taistelua, ja politiikka puolestaan näyttäytyy konfliktuaalisena elämän osa-alueena par excellence siksi, että siinä on suorimmin kyse arvoista, näkökannoista ja intresseistä, jotka itsessään ovat lähtökohtaisesti konfliktuaalisia.

Weberin mukaan "tahdon perimmäisiä kantoja ei voida ratkaista tieteen keinoin" (Parlament, 306), ja "käytännöllisten kantojen" tieteellinen perusteleminen on usein mahdotonta, koska "maailman eri arvojärjestykset ovat ratkaisemattomassa taistelussa [unlöslicher Kampf] keskenään" (Wissenschaft, 99). Weberille arvojen todellisuus on samalla tavalla jakautunut kuin polyteistinen järjestelmä, jossa jumalat "riitelevät [streiten] keskenään" (mt., 100), ja tässä "jumalten taistelussa [Kampf der Götter]" (mts.) ihmisen on vain valittava, ketä näistä jumalista hän haluaa palvella (tai ketä hänen tulee palvella) - tai "milloin yhtä ja milloin toista" (Zwischen, 145).

Myös poliittiset taistelut ovat tämän abstraktin ja antagonistisen arvo-ontologian heijastumaa, sillä politiikassa on kyse nimenomaan kuvatulla tavalla yhteismitattomista arvovalinnoista. Weberin kuuluisassa erottelussa politiikkaa ohjaa absoluuttisen vakaumusetiikan (Gesinnungsethik) sijaan pikemminkin ratkaisujen tekemisen ja kokonaisvastuun kantamisen etiikka (Verantwortungsethik) (Politik, 237). Poliittinen taistelu ei - ainakaan ideaalimuodossaan - ole itsetarkoituksellista taistelua vallasta, vaan oikeina pidettyjen asioiden aktiivista ajamista käytettävissä olevin keinoin ja kokonaisvastuun kantamista usein traagisistakin valinnoista. Ensimmäinen Weberin taistelun käsitteen käyttötapa politiikan yhteydessä on siis taistelu yleisenä eksistentiaalisena periaatteena ja arvojen ikuisena taisteluna: kaikkia arvoja ja toimintalinjoja ei poliittisessa prosessissa voida toteuttaa yhtä aikaa, ja jos arvojen nähdään abstraktilla tasolla heijastavan polyteistisen järjestelmän ikuisia taisteluita, näyttäytyy myös pyrkimys toteuttaa näihin arvoihin perustuvia poliittisia ohjel- mia nimenomaan taisteluna. Tästä näkökulmasta politiikan konfliktuaalisuus on siis "itse asioilta" lainattua konfliktuaalisuutta.

Tulkintani mukaan esimerkiksi seuraava varhaisessa tekstissä "Zur Gründung einer national-sozialen Partei" (1896) esiintyvä politiikan määritelmällinen luonnehdinta on syytä tulkita nimenomaan tästä näkökulmasta:

[P]olitiikka on raskas toimi, ja sillä, joka haluaa ottaa itselleen sen vastuun, että tarttuu isänmaan poliittisen kehityksen pyörän puoliin, täytyy olla vahvat hermot eikä hän saa olla liian tunteellinen harjoittaakseen maallista politiikkaa. Sen, joka sen sijaan haluaa harjoittaa maallista politiikkaa, on oltava ennen kaikkea vapaa kaikista illuusioista ja tunnustettava eräs perustavanlaatuinen tosiasia: ihmisen väistämätön ja ikuinen taistelu ihmisen kanssa maan päällä [den unabwendbaren ewigen Kampf des Menschen mit dem Menschen auf der Erde ... anerkennen], sellaisena kuin se tosiasiassa tapahtuu. Jos näin ei ole, täytyy hänen luopua perustamasta poliittista puoluetta. (Gründung, 28-29.)

Tällä katkelmalla on niin yleisen eksistentiaalisen sävynsä kuin myös yksittäisten sanavalintojensa osalta selvä yhteys Weberin kuuluisaan virkaanastujaispuheeseen "Der Nationalstaat und die Volkwirtschaftspolitik" (1895), jossa taistelu kuvataan niin valtioiden, kansojen kuin yksilöidenkin toimia politiikan, talouden ja kulttuurin tasoilla ohjaavaksi yleiseksi periaatteeksi. Weber ei siteeratussa Gründung-tekstin katkelmassa suoraan määrittele politiikkaa taisteluksi, mutta toteaa kuitenkin, että ikuisen taistelun tosiasia on kaikkea maallista politiikkaa määrittävä taustatekijä ja että nimenomaan se tekee politiikasta raskasta ja hermoja vaativaa. Mainittu ikuinen taistelu on tässä yhteydessä tulkittava yleiseksi eksistentiaaliseksi periaatteeksi, joka määrittää politiikkaa abstraktilla tasolla - ei väitteeksi yksittäisten poliittisten prosessien konfliktiluonteesta, saati sitten piilonormatiiviseksi kehotukseksi oman edun tavoittelemiseen. 
POLITIIKKA AKTIIVISENA

TAISTELUNA
Weberin yhteiskuntateoriassa taistelu esiintyy myös täsmällisenä sosiologisena peruskäsitteenä, joka nivoutuu läheisesti vallan (Macht), herruuden (Herrschaft) ja pyrkimisen (Streben) käsitteisiin. Weber antaa taistelulle seuraavan formaalin määritelmän: "Kutsumme sosiaalista suhdetta taisteluksi [Kampf], jos toiminta tähtää oman tahdon läpiviemiseen toisen osapuolen tai toisten osapuolten vastarintaa vastaan" ( $W u G, 20)$. Toisen luonnehdinnan mukaan taistelu on "toisen käyttäytymistä koskevien odotusten mukaan suuntautunutta pyrkimistä [Streben] viedä oma tahtonsa läpi toisen vastakkaisia pyrkimyksiä vastaan" (Kategorien, 463). On helppo huomata, että sanamuoto on hyvin lähellä Weberin jo klassiseksi muodostunutta vallan (Macht) määritelmää: "Valta tarkoittaa mitä tahansa mahdollisuutta saada läpi oma tahtonsa sosiaalisessa suhteessa myös vastakkaisia pyrkimyksiä vastaan - riippumatta siitä, mihin tämä mahdollisuus perustuu" ( $W u G, 28)$.

Taistelun ja vallan määritelmät kietoutuvat siis toisiinsa: yleisenä yhteiskunnallisena kategoriana taistelu on sellaista toimintaa, jossa pyritään oman tahdon toteuttamiseen tarvittaessa vaikka toisten pyrkimyksiä vastaan, ja valta puolestaan mahdollistaa tämän tavoitteen saavuttamisen. Sellaista vallan erikoistapausta, jossa haluttu päämäärä ja tottelevaisuus saavutetaan suoraan esimerkiksi rationaaliseen, traditionaaliseen tai karismaattiseen legitimiteettiin perustuvan vakiintuneen suhteen nojalla, Weber nimittää herruudeksi (Herrschaft) (WuG, 542). ${ }^{6}$

Weberin politiikkakäsityksen kannalta tärkeä on erityisesti jälkimmäisessä taistelun määritelmässä esiintyvä pyrkimisen (Streben) käsite. Weberille politiikka tarkoittaa "valtaosuuksien tavoittelua [Streben] tai pyrkimystä vaikuttaa vallan jakautumiseen", ja "se, joka harjoittaa politiikkaa, tavoittelee [erstrebt] valtaa" (Politik, 159). Kun politiikka siis on taistelua, mutta toi- saalta valtaan kohdistuvaa pyrkimistä, kietoutuvat taistelun, vallan ja pyrkimisen käsitteet tiukasti toisiinsa. $^{7}$

Parlamentaarinen politiikka on perusluonteeltaan "taistelua ja liittolaisten ja vapaaehtoisen kannattajakunnan värväämistä" (Parlament, 347) ja metaforisemmin "ankaraa ja hidasta kovien lautojen poraamista" (Politik, 251) - siis vaivalloista ja pitkäkestoista toimintaa, joka edellyttää poliitikolta keskeisimpinä ominaisuuksina intohimoa ja vastuuntuntoa asiasisältöjen suhteen sekä suhteellisuudentajua ja tervettä etäisyyttä asioihin ja ihmisiin (Politik, 227). Weberille moderni parlamentaarinen politiikka on selvästi taistelua myös aktiivisen taistelun merkityksessä - siis sosiaalisen vallan tavoittelemista ja käyttämistä omien intressien ajamiseen monimutkaisessa sosiaalisessa asetelmassa, jossa muilla toimijoilla on usein vastakkaisia intressejä.

Tulkintani mukaan ainakin osa Weberin selvästi metaforisista politiikan luonnehdinnoista on tulkittava nimenomaan tässä viitekehyksessä - siis metaforisiksi, mutta silti aktiivisiksi ja pyrkimyksellisiksi taisteluiksi. Vuosien 1917 ja 1918 teksteissä Weber esimerkiksi puhuu Saksassa käydyistä ja tulevaisuudessa odotettavista "vaalioikeustaisteluista" (Wahlrechtskämpfe) (Wahlrecht, 246; Parlament, 406) sekä "muodollisista parlamentaarisista oikeuksista käytävistä taisteluista" (Kampf um formale Parlamentsrechte) (Parlament, 314). Myös esimerkiksi Yhdysvalloissa syntyi Weberin mukaan "mitä katkerin taistelu 'nimityskysymyksistä"” (der erbitterste Kampf um die Frage der "nomination") (Politik, 214). Näissä tapauksissa "Kampf" selvästi viittaa tilanteisiin, joissa eri osapuolten intressit ovat selvästi erotettavissa ja niitä ajetaan aktiivisesti, tiedostetusti ja avoimesti.

\section{TAISTELU JA VALINTA}

Kolmas taistelun käsitteen käyttötapa on taistelu latenttina valintaprosessina. Tämän edellisiä monimutkaisemman taistelun kä- 
sitteen käyttötavan juuret ovat nuoren Weberin darwinilaisissa ajattelutavoissa ja kielenkäytössä, joka periytyy myös Weberin myöhäiseen sosiologiseen teoriaan. ${ }^{8}$

Vuoden 1895 virkaanastujaispuheessa Weber puhuu varsin darwinilaisesti esimerkiksi "mukautumiskyvystä" (Anpassungsfähigkeit) (Nationalstaat, 553), "kasvatustai jalostusprosesseista" (Züchtungsprozesse) (mt., 554) sekä eri kansallisuusryhmien välisestä "taloudellisesta syrjäyttämisestä" (ökonomische Verdrängung) (mt., 550). Keskeisimmät ja yleisimmin toistuvat darwinilaiset ilmaukset ovat kuitenkin toisiinsa tiukasti kytkeytyvät "taistelu olemassaolosta" (Kampf ums Dasein) sekä "valinta" tai "valikoituminen" (Auslese).?

Weber näkee preussilaisten maanviljelijöiden ja puolalaisten kausityöntekijöiden välisen kilpailuasetelman yhtenä esimerkkinä taloudellisesta olemassaolon taistelusta (wirtschaftlicher Kampf ums Dasein) (mt., 558) ja valintaprosessina (Ausleseprozeß) (mt., 553). Myös esimerkiksi kymmenen vuotta myöhemmin julkaistussa Protestanttisessa etiikassa Weber puhuu saksalaisten ja puolalaisten maatyöläisten tilanteesta taloudellisena olemassaolon taisteluna (Protestanttinen, 52; Protestantische, 55-56) ja yleisemmin kapitalistinen järjestelmän harjoittamasta taloudellisesta valinnasta (ökonomische Auslese) (Protestanttinen, 39; Protestantische, 37). Vielä vuonna 1916 julkaistussa kirjoituksessa "Zwischen zwei Gesetzen" Weber puhuu rakkaudettomasta ja säälimättömästä taloudellisesta olemassaolon taistelusta (ökonomischer Kampf ums Dasein) (Zwischen, 144) ja seuraavan vuoden Wahlrecht-artikkelissa hän toteaa yksityisyrittäjän toimivan "vapaassa taistelussa taloudellisesta olemassaolosta [im freien Kampf um das ökonomische Dasein]" (Wahlrecht, 248). Etenkin taloudellisen kilpailun ja kansakuntien välisen kilpailun tapauksissa myös myöhäinen Weber siis hyödyntää darwinilaista käsitteistöä ja darwinilaista ajatusta taistelun ja valinnan periaatteiden yhteen kietoutumisesta.
Edellä käsiteltiin jo taistelun määritelmää Weberin yleisessä sosiologisten peruskäsitteiden esityksessä. Samassa yhteydessä annetaan yleinen yhteiskuntateoreettinen määritelmä myös valinnalle (Auslese), jonka Weber näkee nimenomaan taistelun kategorian alatapauksena:

Sellaista ihmisyksilöiden tai ihmistyyppien (latenttia) olemassaolotaistelua elintai selviytymismahdollisuuksista [Existenzkampf ... um Lebens- oder Ueberlebenschanchen], jossa osapuolten välillä ei ole merkityksellistä kamppailutarkoitusta [Kampfabsicht] toisiaan vastaan, kutsumme "valinnaksi" [Auslese] - "sosiaaliseksi valinnaksi" [soziale Auslese], jos kyse on elävien ihmisten mahdollisuuksista elämässä, ja "biologiseksi valinnaksi" [biologische Auslese], jos kyse on perintöaineksen säilymismahdollisuuksista. ( $W u G, 20$. Korostuksia muutettu.)

Myöhäiselle Weberille "valinta" tässä merkityksessä on siis eräs taistelun muoto, nimi latentille ja ei-intentionaaliselle taistelulle. Michael Zänglen mukaan weberiläinen "olemassaolon taistelu" ei aina ole taistelua oman tahdon tarkoituksellisena läpiviemisenä toisen harjoittamaa vastarintaa vastaan (siis aktiivisena ja pyrkimyksellisenä taisteluna), vaan Weber käyttää sanaa "taistelu" välillä myös toisessa, "objektiivisessa" merkityksessä - viittaamaan siihen yleiseen asiaintilaan, että eri tahojen intressit törmäävät toisiinsa ilman, että nämä ovat siitä välttämättä edes tietoisia. Tällainen taistelun muoto esiintyy Zänglen mukaan etenkin Weberin taloudellisissa näkemyksissä: taloudellinen taistelu perustuu niukkuuteen, mutta niukkuuden ei välttämättä tarvitse muodostaa mitään sosiaalisia suhteita ja johtaa taisteluun termin kapeammassa merkityksessä eli aktiiviseen ja intentionaaliseen taisteluun. (Zängle $1988,35-36) .^{10}$

On tärkeää huomata, ettei weberiläisen valinnan tapahtuminen edellytä osapuolten aktiivista taistelua. Näiden kahden taistelun tyypin välinen erottelu ilmenee jo Weberillä itsellään: 
Huolimatta monista ratkaisevista sattumista ja kohtaloista jokainen tyypillinen ja suuressa mittakaavassa tapahtuva taisteleminen [Kämpfen] ja kilpaileminen [Konkurrieren] johtaa pitemmän päälle lopulta niiden "valintaan" [Auslese], joilla on suuremmissa määrin taistelun voittamisen kannalta keskimäärin tärkeitä henkilökohtaisia ominaisuuksia. [...] Jokainen sosiaalinen valinta ei kuitenkaan ole "taistelu” tässä käytetyssä merkityksessä. "Sosiaalinen valinta" tarkoittaa lähtökohtaisesti enemmänkin vain sitä, että tiettyjä käyttäytymisen tyyppejä ja kenties myös henkilökohtaisten ominaisuuksien tyyppejä suositaan siten, että niiden avulla on suuremmat mahdollisuudet saavuttaa tiettyjä sosiaalisia suhteita (asema "rakastajana", "aviomiehenä", "kansanedustajana", "virkamiehenä", "rakennuspäällikkönä", "pääjohtajana", "menestyvänä liikemiehenä" ja niin edelleen). Tämä ei sinänsä vielä kuitenkaan kerro mitään siitä, toteutuuko tämä suosiminen 'taistelun' ['Kampf'] avulla, eikä siitä, parantaako tämä valinta myös tyypin biologisia selviytymismahdollisuuksia vai onko asia täysin päinvastoin. ( $W u G$, 20-21. Korostuksia muutettu.)

\section{POLITIIKKA LATENTTINA TAISTELUNA}

Esitän, että Weberille myös politiikka on taistelua - edellä käsiteltyjen merkitysten ohella - nimenomaan tällaisen ei-intentionaalisen, passiivisen ja latentin valintataistelun merkityksessä. Poliittisen taistelun periaatteen ja valinnan periaatteen läheinen yhteen kietoutuminen korostuu, kun Weberin sangen lakonisia toteamuksia politiikasta kamppailuna ("Politik ist: Kampf") ei lueta vain irrallisina ja oletetusti kaiken tulkitsemisekseen tarvittavan informaation sisältävinä truismeina, vaan suhteessa Weberin koko perustuslailliseen teoriaan ja sen sosiaalihistorialliseen taustaan. Osoitan seuraavassa, miten ajatus taistelusta latenttina valintaprosessina on luettavissa esiin Weberin parlamentarismia, johtajuutta ja perustuslaillisia järjestelyjä koskevista teorioista.
Valintataistelun idean kannalta keskeisimpiä lähteitä ovat virkaanastujaispuheen lisäksi Weberin kirjoitukset parlamentarismista ensimmäisen maailmansodan loppuaikoina ja Weimarin tasavallan syntyvaiheissa. Niiden aiempaan tapahtumahistorialliseen taustaan kuuluvat muun muassa Vilhelm II:n valtaannousu ja bismarckilaisen ajan päättyminen, työväestön ja sosialismin nousu teollistumisen ja urbanisoitumisen myötä, Saksan myöhäinen imperialismi, kansainvälisten suhteiden kiristyminen, ensimmäinen maailmansota, Saksan tappio ja Versailles'n rauha sekä Weimarin tasavallan synty raskaiden sosiaalisten ongelmien ja poliittisten levottomuuksien varjossa. Tätä kuvaa täydentävät useat Saksan historiallisen kehityksen erityispiirteet, kuten myöhäinen teollistuminen ja demokratisoituminen, parlamentin verraten voimaton asema keisariajalla, porvariston heikkous suhteessa aatelistoon ja porvarillisen vallankumouksen puute sekä esiteollisten ja esiporvarillisten mentaliteettien, rakenteiden ja auktoriteettien säilyminen modernisaatiosta ja äkillisestä demokratisoimisesta huolimatta. ${ }^{11}$ Nämä teemat ovat monin tavoin läsnä Weberin poliittisissa kirjoituksissa. Weber ei kirjoittanut esimerkiksi vallasta, byrokratiasta ja parlamentarismista sinänsä tai abstraktisti, vaan vallasta ja herruudesta sellaisina kuin ne näyttäytyivät oman aikansa yhteiskunnallisten valta-asetelmien ja sosiaalisten kysymysten taustaa vasten, byrokratiasta keisarillisen Saksan ja varhaisen Weimarin tasavallan kontekstissa sekä parlamentarismista suhteessa vuosikymmeniä jatkuneeseen puoliautoritääriseen hallintoon ja pitkään antiparlamentaristiseen traditioon.

Keisariajalla Saksan parlamentti oli verraten heikossa asemassa suhteessa keisariin, valtakunnankansleriin ja liittopäiviin. Weber näki parlamentin harjoittavan lähinnä "negatiivista politiikkaa" eli olevan pikemminkin jarru kuin aktiivinen poliittinen toimija, mikä johti hänen mukaansa myös parlamentin henkisen tason laskemiseen (Parlament, 320, 339-340, 348). Weber 
peräänkuuluttaa Bismarckin jäljiltä sivuosaan päätyneen parlamentin aseman vahvistamista, mutta ei siksi, että olisi kannattanut yleistä demokratisoitumiskehitystä sinänsä. Weber ei ollut sitoutunut demokraattisiin muotoihin mistään periaatteellisista syistä, vaan ainoastaan kontingentisti (Beetham 1974, 101-102). Hänen näkemystään parlamentista ja muista poliittisista instituutioista on syystäkin luonnehdittu "instrumentaaliseksi" (mt., 50) ja "funktionalistiseksi" (Eliaeson 2000, 139), sillä Weberille millään perustuslaillisilla järjestelyillä ei ollut itseisarvoa, vaan ne olivat aina vain välineitä joihinkin päämääriin.

Parlamentin keskeisimpiä funktioita on Weberille esimerkiksi byrokratian kontrolloimisen lisäksi esimerkiksi johtajien tuottaminen. Weberin mielestä parlamentista olisi tehtävä johtajien valitsemisen tai valikoitumisen paikka (Auslesestätte für Führer) (esim. Parlament, 343, 354 ja 424; Wahlrecht, 266). Johtajuutta Weberin perustuslaillisessa mallissa tarvitaan erityisesti siksi, että parlamentin vahvistamista tasapainottavat toisaalta avoimen antidemokraattinen plebisitäärinen periaate ja sitä toteuttava vahvan johtajan hahmo. Weberin mallissa johtaja nousee taloudellisten ja yhteiskunnallisten erityisintressien sekä byrokratian yläpuolelle ja ajattelee kokonaisuuden etua valintojen tekemisen ja kokonaisvastuun kantamisen etiikan hengessä. Massademagogisin keinoin ja karismansa turvin kansaa suostutteleva ja plebisiitillä (Plebiszit) ja huutoäänestyksellä (Akklamation) asemansa saavuttava johtaja on selvä esimodernin ja antidemokraattisen ajattelun jäänne, joka liittyy Saksan sosiaalihistoriallisessa asetelmassa nimenomaan menneen maailman vahvan junkkerijohtajan hahmoon. Se on näin ollen selvästi jännitteisessä suhteessa Weberin varsin moderniin käsitykseen parlamentarismista sekä parlamentin vallan kasvattamisen periaatteeseen.

Weberin kolmas tapa puhua politiikasta taisteluna kytkeytyy suoraan kysymyk- siin parlamentarismista ja vahvasta johtajuudesta. Myös poliittisella taistelulla on nimittäin funktionsa Weberin perustuslaillisessa kokonaisteoriassa: nimenomaan parlamentissa käytävä poliittinen taistelu on se konteksti, jossa poikkeuksellisen lahjakkaat, poliittisesti vastuulliset johtajapersoonallisuudet saavat oppinsa ja josta he kohoavat plebisitäärisen johtajan asemaan. Esimerkiksi Parlament-tekstissä (1918) Weber kirjoittaa seuraavasti:

Kuten usein korostetaan, kaikki politiikka on luonteeltaan taistelua [Das Wesen aller Politik ist [...]: Kampf] , liittolaisten ja vapaaehtoisen seuraajakunnan värväämistä, ja valtion virkaura ei joskus tarjoa minkäänlaista tilaisuutta tähän vaikeaan taitoon harjaantumiseen. Bismarckille Frankfurtin liittopäivät tunnetusti toimivat tällaisena kouluna. Armeijassa koulutus tähtää taisteluun ja voi synnyttää sotilasjohtajia. Modernille poliitikolle kuitenkin nimenomaan parlamentissa ja puolueen puolesta maassa käytävä taistelu on se tietty palaestra, jota ei voida samanarvoisesti korvata millään muulla - kaikkein vähiten virkaylennyksistä käytävällä kilpailulla [Konkurrenz). (Parlament, 347. Kursivointeja muutettu.)

Parlamentti on Weberille siis "koulu" tai "palaestra" (antiikin painipaikka), jota byrokratia ei voi korvata. Samassa tekstissä esiintyy myöhemmin toinen eksplisiittinen ja useasti siteerattu "politiikka on taistelua" -muotoilu, ja jälleen on kyse poliittisten johtajien kasvattamisesta ja valitsemisesta byrokratian kanssa vastakkain asettuvassa kamppailukontekstissa:

Ratkaisevan tärkeää on se, että poliittiseen johtajuuteen joka tapauksessa koulutetaan vain persoonallisuuksia, jotka on valittu poliittisessa taistelussa [ $\mathrm{im}$ politischen Kampf ausgelesen sind], sillä kaikki politiikka on luonteensa mukaisesti taistelua [weil alle Politik dem Wesen nach Kampf ist]. Tämän nyt vain saa keskimäärin paremmin aikaan paljon parjattu "demagogin ammatti" kuin asiakirjahuoneet, jotka kylläkin tarjoavat äärettömästi pa- 
remman koulutuksen asiasisältöjen hallinnointiin. (Parlament, 392. Kursivointeja muutettu.)

Näissä lainauksissa tulee hyvin ilmi taistelun ja valinnan käsitteiden läheinen vuorovaikutus. Lisäksi on huomattava, että johtajien valikoituminen on olennaisesti latentti prosessi. Todellisessa parlamentarismissa valta-asemat ovat Weberin mukaan siinä määrin avoinna, että niiden tavoittelu motivoi yksittäisiä poliitikkoja osallistumaan poliittiseen taisteluun ja alistumaan "tässä kilpataistossa tapahtuvaan valintaan [sich der Auslese dieses Konkurrenzkampfes zu unterziehen]" (Parlament, 340341), eikä tässä ole sinänsä mitään haitallista niin kauan kuin se ei vaikuta itse valintaprosessiin siten, että "johtajaominaisuuksilla siunattujen ihmisten valinta $[A u s$ lese] suoranaisesti estyisi" (Weber, WuG, 862). Yksittäisiä toimijoita motivoi siis mahdollisuus saavuttaa valta-asemia ja niihin liittyvää arvonantoa ja etuoikeuksia, ja politiikan kokonaisprosessin tasolla kansakunta hyötyy saadessaan päteviä johtajia, jotka pystyvät oletettavasti turvaamaan sen kansainvälisen valtapoliittisen aseman ja kehittämään maata.

Yksittäisten poliitikkojen konkreettiset toimet sijaitsevat tavallaan eri tasolla kuin tämä abstrakti valintaprosessi. Weberin kokonaisjärjestelmä ei näytä edellyttävän sitä, että politiikka yleisesti ottaen olisi taistelua aktiivisen taistelun merkityksessä: toisin sanoen poliittisesti kyvykkäimmät ja vastuullisiin johtoasemiin soveltuvimmat yksilöt voivat nousta sosiaalisten valintaprosessien kautta esiin myös silloin, kun yksilöiden välinen kanssakäyminen ei perustu vihamielisiin vastakkainasetteluihin, "kaikkien keinojen käyttämiseen" ja demagogiseen argumentointiin tai kun prosessiin osallistuvat yksilöt eivät edes ole tietoisia vallitsevasta taistelu- ja valinta-asetelmasta. Ajatus politiikasta taisteluna latentin valintataistelun merkityksessä eroaa siten selvästi aktiivisen taistelun ideasta.

\section{JOHTOPÄÄTÖKSET}

Kuten edellä osoitin, voi poliittinen taistelu Weberin laajemman tuotannon yhteydessä tulkittuna tarkoittaa taistelua yleisenä eksistentiaalisena periaatteena, aktiivisena pyrkimisenä tai latenttina valintaprosessina. Kullakin näistä on yhtäläinen asema Weberin politiikkakäsityksessä. Weberiläisestä näkökulmasta jokin yksittäinen poliittinen kysymys ja sen käsittely voi näyttäytyä taisteluna ensinnäkin siksi, että eri toimintalinjoja kannattavien ihmisten mielipide-erot palautuvat sovittamattomiin arvoihin ja arvostuksiin, jolloin myös itse poliittisesta prosessista tulee pysyvästi erillisten lähtökohtien välistä näennäisdialogia. Näitä arvolähtökohtia toteutetaan käytännön politiikassa kokonaisvastuullisten poliittisten ohjelmien muodossa tai degeneroituneemmin puhtaana intressipolitiikkana, ja politiikka on tällöin taistelua myös aktiivisen päämääriin pyrkimisen merkityksessä. Kun tarkastelukulmaa laajennetaan vielä yksittäisten poliittisten kysymysten ja pyrkimysten tuolle puolen, näyttäytyy koko poliittinen prosessi taisteluna siinä mielessä, että se toteuttaa kyvykkäimpien valikoitumista. Weber käyttää kaikista kolmesta poliittisen taistelun muodosta samaa käsitettä Kampf, ja jokainen niistä riittää jo yksin tekemään politiikasta taistelua. Siksi väitelause "politiikka on taistelua" ei weberiläisessä mallissa ainoastaan ole tosi, vaan se on moninkertaisesti ja ylimääräytyneesti tosi.

Artikkelissa esitetty taistelun käsitteen analyysi tekee kyseenalaiseksi weberiläisten käsitteiden ja argumenttien suoraviivaisen käyttämisen politiikan ja poliittisen luonnetta koskevissa nykykeskusteluissa. Vaikka ongelmattomasti läntiseksi liberaaliksi oletettu ja nietzscheläis-darwinilaisesta aatteellisesta aineksesta salonkikelpoiseksi puhdistettu Weber näyttääkin tarjoavan moderneille sosiaalitieteille poliittisten peruskäsitteidensä osalta hyväksyttävän viittauskohteen ja kosolti legitimoivaa voimaa, on kuitenkin pidettävä 
mielessä, että weberiläinen politiikka taisteluna on vain eräs käsitteellinen konstruktio, jolla luonnollisesti on omat teoreettiset, ideologiset ja historialliset sidonnaisuutensa. Tätä seikkaa sivusivat klassikkoteksteissään esimerkiksi Wolfgang J. Mommsen (2004[1959]) ja Raymond Aron (1991[1964]), jotka lukivat Weberiä Bismarckiin, Darwiniin ja Nietzscheen perustuvan valtapoliittisen paradigman ja taistelukeskeisen antropologian kannattajana. Nämä luennat ovat jo osin vanhentuneita ja paikoin epätarkkoja tai jopa tarkoitushakuisia, mutta niiden varoitukset Weberin taistelukäsityksen sidonnaisuuksista ovat nähdäkseni päteviä. Weberin näkemys politiikasta taisteluna kiinnittyy liian tiukasti konfliktiorientoituneisiin aikalaisarvostuksiin, osin kyseenalaisiin aatteellisiin lainoihin sekä historiallisiin erityiskysymyksiin ja keskusteluihin ollakseen neutraali sosiaalitieteellinen havainto tai yhteiskunnallisen todellisuuden yleinen kategoria. Politiikka saattaa kyllä olla "taistelua", mutta se ei ole sitä yksiselitteisesti, apriorisesti, universaalisti, historiattomasti ja kulttuurisista merkityksistä riippumatta.

Weberiläinen ajatus politiikasta taisteluna - Politik als Kampf - on huonosti irrotettavissa kasvualustastaan myös sen vuoksi, ettei se edes ole yksi ja yksiselitteinen doktriini, vaan pikemminkin taistelun käsitteen kolmen eri merkityksen muodostama merkitysten joukko. Weberillä ei yk- sinkertaisesti ole yhtä tiivistä ja yhtenäistä poliittisen taistelun ideaa, joka pätisi ilman täsmennyksiä ja olisi suoraan arkijärjellä ymmärrettävissä, ilman rekonstruktiota hänen politiikan teoriastaan luettavissa ja muihin yhteyksiin sellaisenaan siirrettävissä.

Weberin kolminkertainen taisteludoktriini ja ylileveä taistelun kategoria yhdistyneinä uhmakkaaseen sotilaalliseen retoriikkaan uhkaavat tekstin pintatasolla hävittää näkyvistä taistelun eri merkitysten väliset erot. Politiikka uhkaa jäädä taisteluksi simpliciter. Kolmen taistelutyypin väliset erot ovat kuitenkin todellisia ja vaikuttavia. Weber esimerkiksi korostaa toistuvasti politiikan periaatteellisesti konfliktuaalista arvoperustaa, mutta tämä on oleellisesti eri asia kuin esittää, että politiikka arkipäivän toiminnan tasolla välttämättä olisi tai että sen tulisi olla aktiivista taistelua tai rajua ja piittaamatonta partikulaaristen intressien politiikkaa. Myöskään politiikan valintataistelu-ulottuvuuden korostaminen ei sano paljoakaan siitä, millä keinoin tätä makrotason funktiota toteutetaan, ja itse asiassa liika taistelu ja poliittisen prosessin konfliktuaalisuus saattavat joissain tapauksissa pikemminkin haitata johtajien valikoitumista kuin edistää sitä. Kunkin "politiikka on taistelua" -muotoilun tai politiikan sodankäynniksi kuvaavan metaforisen ilmauksen kohdalla on erikseen tulkittava, mihin poliittisen taistelun ulottuvuuteen siinä viitataan.
1. Esimerkiksi Saksasta Yhdysvaltoihin emigroitunut kansainvälisen politiikan teorian klassikko Hans Morgenthau (1961[1949], 38) toteaa, että "sisäpolitiikka ja kansainvälinen politiikka ovat vain kaksi eri ilmenemismuotoa samalle ilmiölle: valtataistelulle [struggle for power]". Yhtä lailla Weberin vaikutuksen alaisen sosiologi C. Wright Millsin (1959[1956], 171) mukaan "kaikki politiikka on taistelua vallasta [struggle for power]". Myös ranskalaisen Julien Freundin $(1965,543)$ yksiselitteisessä luonnehdinnassa "La politique est lutte" on vahva weberiläinen kaiku.

2. Tarkastelu rajoittuu pääosin kohtiin, joissa Weber puhuu politiikasta taisteluna puhtaan käsitteellisesti, suorasanaisesti ja määritelmänomaisesti, kuten Parlament- 
tekstin iskevässä muotoilussa "Politik ist: Kampf" (Parlament,329n1, vrt. Parlament, 347, 351 ja 392 sekä Politik, 190). Näiden lisäksi myös monissa sellaisissa kohdissa, jotka eivät varsinaisesti koske politiikan perusluonnetta, Weber käyttää ilmauksia, jotka metaforisesti kuvaavat politiikan taisteluksi, kamppailuksi tai sodaksi, poliittiset puolueet toistensa vihollisiksi ja keskustelun argumentit aseiksi. Samassa Parlament-tekstissä Weber esimerkiksi puhuu "poliittisesta taistelusta" (politischer Kampf), "parlamentaarisesta taistelusta" (parlamentarischer Kampf) (340), "puoluetaistelusta" (Parteikampf) (326), "vaalitaistelusta" (Wahlkampf) (327), "vaalitaistelukentästä" (Wahlschlachtfeld) (325), "vihollisista ja kilpailijoista" (Feinde und Konkurrenten) (392), "vastustajista" (Gegner) (388) sekä "iskusanoista" (Schlagworte) (402). Weberin varsinaiset politologiset, sosiologiset ja filosofiset näkemykset ja väitelauseet politiikasta taisteluna kytkeytyvät niin tiiviisti tällaisiin kielen tasolla ikään kuin ohimennen esitettyihin metaforisiin luonnehdintoihin, ettei käsitteellistä ja metaforista tasoa voida kokonaan erottaa toisistaan. Pikemminkin retorisen tason sinne tänne hajaantuneet taistelumetaforat näyttävät tekevän huomaamattomammin samaa työtä kuin eksplisiittiset väitteet taistelun kategorian keskeisyydestä kulttuurielämässä. Ne myös näyttävät olevan tehokas kirjallinen keino levittää näennäisesti triviaalien ilmausten muodossa perustavanlaatuisia agonistisia maailmankatsomuksellisia ja antropologisia oletuksia koko Weberin kirjalliseen korpukseen. Tällaisia metaforisia ilmauksia ja niiden dynamiikkaa ei tässä yhteydessä kuitenkaan lähemmin analysoida.

3. Nietzschen vaikutus Weberin yleisiin intellektuaalisiin orientaatioihin ja osaan hänen käyttämäänsä sanastoa on tutkimuksessa yleisesti hyväksytty tosiasia, mutta se näyttää sittenkin pysyvän pikemminkin inspiroinnin ja yleisen samanhenkisyyden tasolla kuin ilmenevän varsinaisena argumenttien ja käsitteiden käyttötapojen periytymisenä. Weber ei esimerkiksi juurikaan suoraan viittaa Nietzscheen. (Weberin nietzscheläisyydestä, ks. esim. Fleischmann 1964 ja Hennis 1987, 167-191.)

4. Tätä havainnollistaa esimerkiksi vuonna
1907 julkaistu mietelmäkirja (Spruchwörterbuch, 440), joka sisältää muun muassa seuraavat sitaatit: "Myös taistelu ja vastarinta on jo puoli voittoa, ja sen, mikä teoista puuttuu, täydentää tahto" (Runoilija Leopold Schefer, 1784-1862); "Taistelua on kaikkialla, ilman taistelua ei ole elämää; ja jos haluamme jatkaa elämäämme, täytyy meidän myös varautua uusiin taisteluihin" (Otto von Bismarck, 1895) sekä "Taistelu virkistää rintaa, voitto karaisee" (Näytelmäkirjailija Gerhardt Hauptmann, 1898). Samoin vuoden 1910 painos eräästä suositusta sitaattikokoelmasta (Geflügelte Worte, 168) kuvaa Goethen sanoin ihmisen elämän ylipäänsä taisteluna: "Denn ich bin ein Mensch gewesen, / Und das heißt ein Kämpfer sein" ("Sillä olin ihminen, / ja ihminen on taistelija").

5. Aikansa tapojen mukaisesti nuori Weber esimerkiksi osallistui aktiivisesti ylioppilasjärjestöjen toimintaan juomakilpailuista kaksintaisteluihin, ja Marianne Weberin (1950, 79-80) karikatyyrimäisen luonnehdinnan mukaan näiden aktiviteettien myötä arasta ja hintelästä nuorukaisesta kasvoi lyhyessä ajassa maskuliinisuutta, etäisyyden ottamista ja muodollista käytöstä korostava roteva mies. Weber suhtautui kaksintaisteluinstituutioon varsin myönteisesti läpi elämänsä ja oli vielä aikamiehenä valmis puolustamaan ensin vaimonsa kunniaa ja myöhemmin omaa loukattua ylpeyttään asein. Ylipäänsä maskuliinisia arvoja korostaneiden herraseurojen muisto näyttää Radkaun (2005, 75-76) mukaan säilyneen Weberin myöhemmässäkin ajattelussa sosiaalisen elämän peruskokemuksena.

6. Herruus on "mahdollisuus pakottaa toisten käyttäytyminen oman tahdon mukaiseksi" (WuG, 542) sekä yksinkertaisesti "mahdollisuus siihen, että tietynsisältöistä käskyä totellaan määrätyssä ihmisten joukossa" (mt., 28).

7. Kari Palonen (1998, 156-176) lukee Weberin "pyrkimistä", "taistelua" ja "valtaa" poliittisen kontingenssia koskevina topoksina sekä tarkastelee näiden keskinäissuhteita.

8. Weberin suhdetta darwinismiin ja sosiaalidarwinismiin ei tässä artikkelissa käsitellä yksityiskohtaisemmin (ks. Pankakoski 2007, 65-98). On kuitenkin huomautettava, ettei Weber missään tapauksessa ollut darwinilainen sanan tiukassa tieteellisessä 
merkityksessä tai sosiaalidarwinilainen sanan missään (etenkään ideologisessa) merkityksessä. Pikemminkin Weber käyttää darwinilaista käsitteistöä ja darwinilaisia ajatuskulkuja omiin teoreettisiin tarkoituksiinsa epäilemättä osin ironisestikin tai ainakin tietoisena niiden alkuperästä.

9. Yksinkertaisuuden vuoksi suomennan Auslesen pääsääntöisesti "valinnaksi" pikemminkin kuin "valikoitumiseksi”. Tätä käännösvalintaa tukee jo se, että esimerkiksi darwinilaisen teorian yhteydessä puhutaan suomeksi yleisesti nimenomaan "luonnonvalinnasta". On kuitenkin syytä pitää mielessä, että kyse ei ole tietoisesta ja intentionaalisesta prosessista.

10. Tämä erottelu aktiivisen ja latentin taistelun välillä sisältyy vähintäänkin implisiittisenä jo Darwinin olemassaolon taistelun alkuperäiseen muotoiluun (esim. Darwin 1975[18561858], 186-188).

11. Nämä ja muut samansuuntaiset tekijät on niin sanotussa Sonderweg-tutkimuksessa nostettu Saksan muista länsimaista poikkeavan historiallisen ja poliittisen kehityksen keskeisiksi syiksi ja selittämään fasismin syntyä ja kansallissosialistien valtaannousua. Teoriasuuntaus on saanut osakseen myös kritiikkiä, eikä sen esiin nostamien tendenssien huomioimisen tule tulkita tarkoittavan varsinaisen erityistieteesin implisiittistäkään hyväksymistä. (Sonderweg-teorioista yleisesti, ks. esim. Steinmetz 2000[1997].)

\section{K I R J A L LIS U U S}

\section{WEBER-LÄHTEET:}

Weber, Max (1993[1895]) "Der Nationalstaat und die Volkwirtschaftspolitik. Akademische Antrittsrede". Max Weber Gesamtausgabe, I:4, hrsg. von Wolfgang J. Mommsen in Zusammenarbeit mit Rita Aldenhoff, 2. Halbband, J. C. B. Mohr (Paul Siebeck), Tübingen, 542-574. [ = Nationalstaat $]$

Weber, Max (1988[1896]) "Zur Gründung einer national-sozialen Partei". Gesammelte Politische Schriften. 5. Auflage, hrsg. von Johannes Winckelmann. J. C. B. Mohr (Paul Siebeck), Tübingen, [=GPS], 26-29. [ = Gründung]

Weber, Max (1947[1904-1905]) Die Protestantische Ethik und der Geist des Kapitalismus. Teoksessa Gesammelte Aufsätze zur Religionssoziologie, vierte, photomechanisch gedruckte Auflage, J. C. B. Mohr (Paul Siebeck), Tübingen, 17-206. [ = Protestantische]

Weber, Max (1990[1904-1905]) Protestanttinen etiikka ja kapitalismin henki. Suom. Timo Kyntäjä. Toinen painos. WSOY, PorvooHelsinki-Juva. [Alkuteos Die protestantische Ethik und der Geist des Kapitalismus, 1904-1905.] [ = Protestanttinen]

Weber, Max (1951[1913]) "Ueber einige Kategorien des verstehenden Soziologie". Teoksessa Gesammelte Aufsätze zur
Wissenschaftslehre (hrsg. Johannes Winckelmann), 2. Auflage, J. C. B. Mohr (Paul Siebeck), Tübingen, 427-474. [ = Kategorien]

Weber, Max (1988[1916]) "Zwischen zwei Gesetzen". GPS, 142-145. [ = Zwischen]

Weber, Max (1951[1917]) "Der Sinn der 'Wertfreiheit' der soziologischen und ökonomischen Wissenschaften". Teoksessa Gesammelte Aufsätze zur Wissenschaftslehre (hrsg. Johannes Winckelmann), 2. Auflage, J. C. B. Mohr (Paul Siebeck), Tübingen, 475-526. [ = Wertfreiheit $]$

Weber, Max (1988[1917]) "Wahlrecht und Demokratie in Deutschland". GPS, 245291. [ = Wahlrecht $]$

Weber, Max (1988[1918]) "Parlament und Regierung im neugeordneten Deutschland". GPS, 306-443. [ = Parlament $]$

Weber, Max (1992a[1919]) "Wissenschaft als Beruf". Max Weber Gesamtausgabe, I:17, hrsg. von Wolfgang J. Mommsen und Wolfgang Schluchter, J. C. B. Mohr (Paul Siebeck), Tübingen, 70-111. [ = Wissenschaft]

Weber, Max (1992b[1919]) "Politik als Beruf". Max Weber Gesamtausgabe, I:17, hrsg. von Wolfgang J. Mommsen und Wolfgang Schluchter, J. C. B. Mohr (Paul Siebeck), Tübingen, 157-252. [ = Politik $]$

Weber, Max (1956[1922]) Wirtschaft und Gesellschaft. Grundriss der verstehenden 
Soziologie. 2 Bände, Vierte, neu herausgegebene auflage, besorgt von Johannes Winckelmann, J. C. B. Mohr (Paul Siebeck), Tübingen. $[=W u G]$

\section{MUUT LÄHTEET:}

Aron, Raymond (1991[1964]) "Max Weber und die Machtpolitik". Teoksessa Peter Hamilton (toim.): Max Weber. Critical Assessments 2. Volume I. Routledge, London et al., 24-39.

Beetham, David (1974) Max Weber and the Theory of Modern Politics. George Allen \& Unwin Ltd, London.

Darwin, Charles (1975[1856-1858]) Charles Darwin's Natural Selection. Being the Second Part of his Big Species Book Written From 1856 to 1858. Ed. R. C. Stauffer, Cambridge University Press, Cambridge.

Eliaeson, Sven (2000) "Constitutional Caesarism: Weber's Politics in their German Context". Teoksessa Stephen Turner (toim.): The Cambridge Companion to Weber. Cambridge University Press, Cambridge et al., 131-148.

Fleischmann, Eugène (1964) "De Weber à Nietzsche". Archives européennes de sociologie, 5, 1964, 190-238.

Freund, Julien (1965) L'essence du politique. Éditions Sirey, Paris.

Geflügelte Worte. Die Zitatenschatz des deutschen Volkes. Gesammelt und erläutert von Georg Büchmann, Haude \& Spener, Berlin, 1910.

Hennis, Wilhelm (1987) Max Webers Fragestellung. Studien zu Biographie des Werks. J. C. B. Mohr (Paul Siebeck), Tübingen.

Mills, C. Wright (1959[1956]) The Power Elite. Oxford University Press, New York.

Mommsen, Wolfgang J. (2004[1959]) Max Weber und die deutsche Politik 1890-1920. 3., verbesserte Auflage. Mohr Siebeck, Tübingen.

Morgenthau, Hans J. (1961[1949]) Politics
Among Nations. The Struggle for Power and Peace. Third edition. Alfred A. Knopf, New York.

Palonen, Kari (1998) Das 'Webersche Moment'. Zur Kontingenz des Politischen. Westdeutscher Verlag, Opladen/Wiesbaden.

Pankakoski, Timo (2007) Politiikan taistelumetaforiikka Max Weberin politiikan teoriassa. Julkaisematon lisensiaatintutkimus, Yleisen valtio-opin laitos, Helsingin yliopisto.

Radkau, Joachim (2005) Max Weber. Die Leidenschaft des Denkens. Carl Hanser Verlag, München - Wien.

Simmel, Georg (1995[1903]) "Soziologie der Konkurrenz". Gesamtausgabe 7: Aufsätze und Abhandlungen 1901-1908, Band 1. Hrsg. von Rüdiger Kramme et al., Suhrkamp, Frankfurt am Main, 221-246.

Spruchwörterbuch. Hrsg. von Franz Joseph freiherr von Lipperheide, Haude \& Spenersche Verlagsbuchhandlung, Berlin, 1962[1907].

Steinmetz, George (2000[1997]) "German Exceptionalism and the Origins of Nazism: The Career of a Concept". Teoksessa Ian Kershaw \& Moshe Lewin (toim.): Stalinism and Nazism. Dictatorships in Comparison. Cambridge University Press, Cambridge et al., 251-284.

Weber, Marianne (1950) Max Weber. Ein Lebensbild. Verlag Lambert Schneider, Heidelberg.

Winckelmann, Johannes (1966) "Max Webers Verständnis von Mensch und Gesellschaft". Teoksessa Karl English, Bernhard Pfister \& Johannes Winckelmann (toim.): Max Weber. Gedächtnissschrift der LudwigMaximilians-Universität München zur 100. Wiederkehr seines Geburtstages 1964. Duncker \& Humblot, Berlin, 195-243.

Zängle, Michael (1988) Max Webers Staatstheorie im Kontext seines Werkes. Beiträge zur Politischen Wissenschaft, 53. Duncker \& Humblot, Berlin. 